\title{
PENGARUH STRATEGI MATHEMATICAL HABITS OF MIND (MHM) BERBASIS MASALAH TERHADAP KREATIVITAS SISWA
}

\author{
Ali Mahmudi dan Utari Sumarmo \\ FMIPA Universitas Negeri Yogyakarta dan Sekolah Pascasarjana UPI \\ (ali_uny73@yahoo.com; HP: 081328728725)
}

\begin{abstract}
The Effects of the Problem-Based MHM Strategy on the Mathematical Creative Thinking Ability and Perception of Creativity. This paper presents findings from a quasi-experimental study with a static group comparison design by using the problem-based MHM instructional strategy conducted to investigate students' mathematical creative thinking ability (MCTA) and perception of creativity (PoC). The study involved 126 students from two junior high schools of high and middle categories in Yogyakarta. The instruments were a test of Mathematical Prior Ability (MPA), a test of MCTA, and a scale of PoC. The data were analyzed using the two-way ANOVA and Chi-Square test. The study found that the problem-based MHM instructional strategy was able to improve students' MCTA better than the conventional instruction, there was association between MCTA and PoC, there was an interaction between the school category and the instructional category on $\mathrm{PoC}$, and there was no such interaction on MCTA.
\end{abstract}

Keywords: problem-based MHM instructional strategy, mathematical creative thinking ability, perception of creativity

\section{PENDAHULUAN}

Dalam kehidupannya, tiap individu senantiasa menghadapi masalah, dalam skala sempit maupun luas, sederhana maupun kompleks. Kesuksesan individu antara lain ditentukan oleh kreativitasnya dalam menyelesaikan masalah. Individu kreatif memiliki beberapa karakteristik yang berbeda dengan individu biasa. Individu kreatif memandang masalah sebagai tantangan yang harus dihadapi, bukan dihindari. Individu kreatif juga memandang masalah dari berbagai perspektif yang memungkinkannya memperoleh berbagai alternatif solusi.
Kemampuan berpikir kreatif merupakan salah satu kemampuan yang dikehendaki dunia kerja (Career Center Maine Department of Labor USA, 2001). Selain itu, pengembangan kemampuan berpikir kreatif merupakan salah satu fokus pembelajaran matematika. Melalui pembelajaran matematika, siswa diharapkan memiliki kemampuan berpikir logis, analitis, sistematis, kritis, dan kreatif, serta memiliki kemampuan bekerja sama (Depdiknas, 2004).

Institusi pendidikan memiliki peran dan tanggung jawab untuk membekali peserta didik kemampuan-kemampuan yang berguna bagi kehidupan mereka. 
Namun demikian, peran dan tanggung jawab tersebut tampaknya belum dilakukan secara optimal. Hasil penelitian McGregor (2007) menunjukkan bahwa sekitar dua pertiga orang di Amerika yang berusia 16 sampai 25 tahun menyatakan bahwa institusi pendidikan tidak membekali mereka kemampuankemampuan penting yang diperlukan untuk menghadapi tantangan kehidupan. Kemampuan-kemampuan tersebut diantaranya adalah kemampuan berpikir kreatif.

Isaksen, et al. (Grieshober, 2004) mendefinisikan berpikir kreatif sebagai proses konstruksi ide yang menekankan pada aspek kelancaran, keluwesan, kebaruan, dan keterincian. Komponen kebaruan dalam berpikir kreatif juga dikemukakan oleh McGregor (2007); Livne (2008); dan Martin (2009). Mc Gregor (2007) mendefinisikan berpikir kreatif sebagai berpikir yang mengarah pada pemerolehan wawasan baru, pendekatan baru, perspektif baru, atau cara baru dalam memahami sesuatu. Menurut Livne (2008), kemampuan berpikir kreatif merujuk pada kemampuan untukmenghasilkan solusi bervariasi yang bersifat baru terhadap masalah yang bersifat terbuka. Martin (2009) mendefinisikan kemampuan berpikir kreatif sebagai kemampuan untuk menghasilkan ide atau cara baru dalam menghasilkan suatu produk.

Pengembangan kemampuan berpikir kreatif dipengaruhi oleh berbagai faktor. Salah satu faktor tersebut adalah persepsi terhadap kreativitas. Secara umum, terdapat dua pandangan berbeda mengenai kreativitas. Pandangan pertama menyatakan bahwa kreativitas hanya dimiliki oleh individu dengan karakteristik tertentu (Berg, 1999; Getzel \& Jackson dalam Alexander, 2007; Briggs dan Davis, 2008). Menurut Berg (2009), kreativitas hanya dimiliki oleh individu jenius berkemampuan luar biasa pada bidang-bidang tertentu, seperti sains, sastra, atau seni. Kreativitas juga dipandang bersifat magis dan misterius yang melibatkan aktivitas bawah sadar. Sementara, menurut Getzel dan Jackson (Alexander, 2007), kreativitas sering dikaitkan dengan sikap mengganggu dan membuat gaduh yang sulit dikendalikan. Briggs dan Davis (2008) melaporkan bahwa hanya sedikit mahasiswa yang memandang bahwa kreativitas berkaitan dengan cara berpikir.

Pandangan kedua mengenai kreativitas dinyatakan oleh Dunbar dan Weisberg (Matlin, 2003) dan Treffinger (Alexander, 2007) bahwa kreativitas dapat dimiliki oleh individu dengan kemampuan biasa. Dunbar dan Weisberg (Matlin, 2003) menyatakan bahwa kreativitas merujuk pada penggunaan kemampuan berpikir dalam menyelesaikan masalah sehari-hari yang dapat dilakukan oleh individu berkemampuan biasa. Treffinger (Alexander, 2007) mengemukakan bahwa setiap individu pada dasarnya memiliki potensi kreatif. Pandangan-pandangan tersebut menegaskan bahwa kreativitas dapat dimiliki oleh siapapun, tidak hanya oleh individu berkemampuan luar biasa.

Pengembangan kemampuan berpikir kreatif perlu dilakukan secara simultan dengan pengembangan persepsi yang tepat terhadap kreativitas. Hal ini sesuai dengan hasil penelitian Mann (2005) yang menunjukkan bahwa per- 
sepsi terhadap kreativitas merupakan salah satu penduga yang baik bagi kreativitas. Siswa yang memiliki persepsi positif terhadap kreativitas lebih berpotensi menjadi kreatif. Sebaliknya, persepsi yang tidak tepat menjadikan pengembangan kreativitas tidak mudah dilakukan. Hal ini dapat dipahami karena individu yang memiliki persepsi tidak tepat, seperti meyakini diri tidak kreatif dan di sisi lain juga meyakini bahwa kreativitas hanya dimiliki oleh individu jenius, tentu tidak akan melakukan upaya sadar untuk mengembangkan kemampuan berpikir kreatif.

Kesuksesan individu sangat ditentukan oleh kebiasaan-kebiasaan yang dilakukan. Kebiasaan-kebiasaan positif yang dilakukan secara konsisten berpotensi dapat membentuk kemampuankemampuan positif. Cara berpikir demikian dirujuk oleh Millman dan Jacobbe (2008) untuk mengembangkan strategi Mathematical Habits of Mind (MHM) yang dapat digunakan untuk membangun kemampuan berpikir kreatif melalui pembiasaan atau pembudayaan berpikir matematis. Mengembangkan kemampuan berpikir kreatif matematis dengan cara mengembangkan kebiasaan berpikir matematis sejalan dengan pendapat Sternberg (2006) yang memandang kreativitas sebagai kebiasaan. Hasil penelitian Jacobbe (Millman dan Jacobbe, 2008) menunjukkan bahwa siswa yang mengikuti pembelajaran dengan strategi MHM berbasis masalah memiliki kinerja yang baik dalam pemecahan masalah.

Menurut Millman dan Jacobbe (2008), strategi MHM terdiri atas enam kegiatan, yaitu (1) mengeksplorasi ide- ide matematis; (2) merefleksi kebenaran atau kesesuaian jawaban; (3) mengidentifikasi strategi yang dapat digunakan untuk menyelesaikan masalah yang lebih luas; (4) bertanya pada diri sendiri apakah terdapat "sesuatu yang lebih" dari aktivitas matematika yang dilakukan (generalisasi); (5)memformulasi pertanyaan; dan (6) mengkonstruksi contoh. Kegiatan-kegiatan ini dapat dipandang sebagai kebiasaan-kebiasaan berpikir matematis yang apabila dilakukan secara konsisten berpotensi dapat membentuk kemampuan berpikir kratif matematis.

Kemampuan berpikir kreatif matematis tidak tumbuh di ruang hampa, melainkan memerlukan daya dukung. Menurut Isaksen (Alexander, 2007), daya dukung tersebut dapat berupa konteks, situasi, atau faktor sosial. Konteks tersebut dapat berupa masalah yang menantang sebagai pemicu bagi proses belajar siswa. Dalam hal ini, masalah tidak lagi dipandang sebagai penerapan konsep yang ditempatkan di akhir pembelajaran,melainkan di tahap awal pembelajaran sebagai pemicu proses belajar siswa dalam membangun pengetahuan dan mengembangkan kemampuan matematis. Pembelajaran yang memiliki karakteristik demikian disebut pembelajaran berbasis masalah (Fogarty, 1997; Center for Instructional Development $\mathcal{E}$ Research, 2004; dan Roh, 2003).

Keunggulan pembelajaran berbasis masalah dibandingkan pembelajaran konvensional dilaporkan beberapa peneliti, seperti Permana (2004) serta Ratnaningsih dan Herman (2006). Permana (2004) melaporkan bahwa siswa yang mengikuti pembelajaran berbasis masa- 
lah memiliki kemampuan pemecahan masalah, penalaran, dan komunikasi matematis yang lebih baik daripada siswa yang mengikuti pembelajaran secara konvensional. Ratnaningsih dan Herman (2006) melaporkan bahwa siswa yang mengikuti pembelajaran berbasis masalah memiliki kemampuan penalaran matematis yang lebih baik daripada siswa yang mengikuti pembelajaran secara konvensional.

Uraian di atas menunjukkan bahwa strategi MHM dan pembelajaran berbasis masalah memiliki potensi untuk mengembangkan kemampuan berpikir kreatif. Hal demikian mendorong peneliti untuk mengintegrasikan pembelajaran berbasis masalah dengan strategi MHM. Selanjutnya, pembelajaran demikian disebut pembelajaran dengan strategi MHM berbasis masalah. Melalui pembelajaran demikian, secara kolaboratif siswa melakukan kebiasaan-kebiasaan berpikir matematis untuk mengeksplorasi masalah, fakta, informasi, data, atau strategi penyelesaian masalah. Siswa juga mengkonstruksi contoh dan memformulasi pertanyaan terkait pengetahuan yang telah dibangun atau soal yang telah diselesaikan. Melalui kegiatan-kegiatan demikian, siswa dapat membangun pengetahuan dan sekaligus mengembangkan kemampuan berpikir kreatif matematis. Pembelajaran dengan strategi MHM berbasis masalah juga berpotensi sebagai sarana untuk mengembangkan persepsi yang tepat terhadap kreativitas. Misalnya, melalui pembelajaran demikian, siswa meyakini bahwa soal matematika dapat memiliki lebih dari satu solusi atau strategi penyelesaian. Strategi MHM ber- basis masalah perlu dipraktikkan dalam pembelajaran matematika untuk selanjutnya dikaji pengaruhnya terhadap kemampuan berpikir kreatif matematis dan persepsi terhadap kreativitas.

\section{METODE}

Penelitian ini merupakan penelitian kuasi-eksperimen dengan desain perbandingan kelompok statis (Ruseffendi, 2005). Penelitian ini melibatkan dua kategori kelas sampel, yaitu kelas eksperimen dan kelas kontrol. Kelas-kelas sampel tidak dibentuk dengan cara menempatkan secara acak subjek-subjek penelitian ke dalam kelas-kelas sampel tersebut, melainkan menggunakan kelas-kelas yang ada. Di kelas eksperimen dan kelas kontrol berturut-turut dilaksanakan pembelajaran dengan strategi MHM berbasis masalah dan pembelajaran secara konvensional. Pada akhir pembelajaran, siswa kedua kelas diberi tes kemampuan berpikir kreatif matematis dan skala persepsi terhadap kreativitas. Penelitian ini dilaksanakan pada Juli sampai November 2009.

Penelitian ini mengkaji pengaruh pembelajaran dengan strategi MHM berbasis masalah terhadap kemampuan berpikir kreatif matematis dan persepsi terhadap kreativitas. Pengkajian lebih komprehensif dilakukan dengan meninjau atau melibatkan faktor Kemampuan Awal Matematis (KAM) dan faktor kategori sekolah sebagai variabel kontrol.

Populasi penelitian ini adalah seluruh siswa dari dua SMP di Kota Yogyakarta dengan kategori berbeda, yaitu kategori atas dan kategori sedang. Dari masing-masing kategori sekolah terse- 
but dipilih dua kelas sampel, yaitu kelas eksperimen dan kelas kontrol. Kelaskelas ini tidak ditentukan secara acak, melainkan dipilih kelas-kelas yang tidak memiliki jadwal beririsan karena peneliti bertindak sebagai pengajar. Pada sekolah kategori atas, banyaknya siswa kelas eksperimen dan kelas kontrol masing-masing adalah 31 siswa. Pada sekolah kategori sedang, masing-masing adalah 32 siswa.

Tes kemampuan berpikir kreatif matematis terdiri atas 6 butir soal uraian untuk mengukur aspek-aspek kemampuan berpikir kreatif matematis, yaitu aspek kelancaran, keluwesan, kebaruan, dan keterincian. Berikut adalah contoh soal kemampuan berpikir kreatif matematis.

Ali dan Joko melakukan perjalanan dari kota A ke kota B. Mereka berangkat pada saat yang sama dan melalui jalan yang sama. Ali menempuh separuh jarak perjalanannya dengan kecepatan $V_{1}$ dan separuh jarak berikutnya dengan kecepatan $V_{2}$. Joko menempuh separuh waktu perjalanannya dengan kecepatan $V_{1}$ dan separuh waktu berikutnya dengan kecepatan $V_{2}$. Siapakah yang lebih dahulu sampai ke kota B? Gunakan beberapa cara untuk menjelaskan jawabanmu.

Skala persepsi terhadap kreativitas terdiri atas 15 butir pernyataan masingmasing dengan 4 kategori pilihan, yaitu sangat setuju, setuju, tidak setuju, dan sangat tidak setuju. Persepsi terhadap kreativitas mencakup lima aspek, yaitu aspek potensi kreatif, lingkup kreativitas, karakteristik ide kreatif, individu kreatif, dan pengembangan kreativitas. Berikut diberikan beberapa contoh butir skala persepsi terhadap kreativitas.

- Orang berkemampuan biasa bisa menjadi kreatif.

- Kreativitas diperlukan pada semua bidang kehidupan, termasuk matematika.

- Kreativitas dapat dihasilkan dengan menggabungkan, mengubah, atau memperbaiki ide-ide yang telah ada.

- Orang kreatif sulit menerima pendapat yang berbeda dari orang lain.

- Pembelajaran matematika dapat digunakan untuk mengembangkan kreativitas siswa.

Analisis data menggunakan anova duajalur untuk menguji pengaruh pembelajaran dengan strategi MHM berbasis masalah terhadap kemampuan berpikir kreatif matematis dan persepsi terhadap kreativitas dengan meninjau faktor kategori sekolah dan faktor KAM. Pengujian asosiasi antara kemampuan berpikir kreatif matematis dengan persepsi terhadap kreativitas digunakan uji Chi-Kuadrat.

\section{HASIL}

Berikut berturut-turut disajikan deskripsi data kemampuan berpikir kreatif matematis siswa dan persepsi siswa terhadap kreativitas. 
Tabel 1. Kemampuan Berpikir Kreatif Matematis Siswa Berdasarkan Kategori KAM, Sekolah, dan Pembelajaran

\begin{tabular}{|c|c|c|c|c|c|c|c|}
\hline \multirow{2}{*}{$\begin{array}{c}\text { Kategori } \\
\text { KAM }\end{array}$} & \multirow{2}{*}{$\begin{array}{c}\text { Ukuran } \\
\text { Statatistik }\end{array}$} & \multicolumn{3}{|c|}{ MHM Berbasis Masalah } & \multicolumn{3}{|c|}{ Konvensional } \\
\hline & & $\begin{array}{c}\text { Sekolah } \\
\text { Atas }\end{array}$ & $\begin{array}{l}\text { Sekolah } \\
\text { Sedang }\end{array}$ & Total & $\begin{array}{c}\text { Sekolah } \\
\text { Atas }\end{array}$ & $\begin{array}{l}\text { Sekolah } \\
\text { Sedang }\end{array}$ & Total \\
\hline \multirow[t]{3}{*}{ Tinggi } & Banyak Siswa & 10 & 2 & 12 & 9 & 0 & 9 \\
\hline & Rata-rata & 43,90 & 43,50 & 43,83 & 41,56 & 0 & 41,56 \\
\hline & Simpangan Baku & 8,17 & 6,36 & 7,64 & 10,84 & 0 & 10.84 \\
\hline \multirow[t]{3}{*}{ Sedang } & Banyak Siswa & 11 & 11 & 22 & 12 & 19 & 31 \\
\hline & Rata-rata & 37,46 & 40,64 & 39,05 & 33,42 & 32,79 & 33,10 \\
\hline & Simpangan Baku & 13,71 & 9,86 & 11,77 & 9.81 & 12,01 & 11,04 \\
\hline \multirow[t]{3}{*}{ Rendah } & Banyak Siswa & 10 & 19 & 29 & 10 & 13 & 23 \\
\hline & Rata-rata & 39,80 & 36,90 & 37,90 & 30,10 & 25,00 & 27,51 \\
\hline & Simpangan Baku & 10,61 & 9,40 & 9,75 & 8,21 & 12,68 & 11.02 \\
\hline \multirow[t]{3}{*}{ Total } & Banyak Siswa & 31 & 32 & 63 & 31 & 32 & 63 \\
\hline & Rata-rata & 40,29 & 38,59 & 39,43 & 34,71 & 29,63 & 32,13 \\
\hline & Simpangan Baku & 11,13 & 9,42 & 10,25 & 10,42 & 12,68 & 11,81 \\
\hline
\end{tabular}

Catatan: Skor ideal adalah 70

Tabel 2. Persepsi Siswa terhadap Kreativitas Berdasarkan Kategori KAM, Sekolah dan Pembelajaran

\begin{tabular}{|c|c|c|c|c|c|c|c|}
\hline \multirow{2}{*}{$\begin{array}{c}\text { Kategori } \\
\text { KAM }\end{array}$} & \multirow{2}{*}{$\begin{array}{c}\text { Ukuran } \\
\text { Statatistik }\end{array}$} & \multicolumn{3}{|c|}{ Pembelajaran MHM } & \multicolumn{3}{|c|}{ Pembelajaran Konvensional } \\
\hline & & $\begin{array}{c}\text { Sekolah } \\
\text { Atas }\end{array}$ & $\begin{array}{l}\text { Sekolah } \\
\text { Sedang }\end{array}$ & Total & $\begin{array}{c}\text { Sekolah } \\
\text { Atas }\end{array}$ & $\begin{array}{l}\text { Sekolah } \\
\text { Sedang }\end{array}$ & Total \\
\hline \multirow{3}{*}{ Tinggi } & Banyak Siswa & 10 & 2 & 12 & 9 & 0 & 9 \\
\hline & Rata-rata & 45,64 & 38,97 & 44,53 & 41,95 & 0 & 41,95 \\
\hline & Simpangan Baku & 6,84 & 1.88 & 6,73 & 6,17 & 0 & 6,17 \\
\hline \multirow{3}{*}{ Sedang } & Banyak Siswa & 11 & 11 & 22 & 12 & 19 & 31 \\
\hline & Rata-rata & 43,24 & 42,66 & 42.95 & 46,90 & 38,77 & 41,91 \\
\hline & Simpangan Baku & 4.81 & 2,36 & 3,71 & 6,04 & 5,56 & 6,93 \\
\hline \multirow{3}{*}{ Rendah } & Banyak Siswa & 10 & 19 & 29 & 10 & 13 & 23 \\
\hline & Rata-rata & 47,00 & 44,71 & 45,50 & 43,51 & 37,57 & 40,15 \\
\hline & Simpangan Baku & 3,55 & 5,349 & 4,87 & 3,99 & 4,85 & 5,33 \\
\hline \multirow[t]{3}{*}{ Total } & Banyak Siswa & 31 & 32 & 63 & 31 & 32 & 63 \\
\hline & Rata-rata & 45,23 & 43,65 & 44,42 & 44,37 & 38,28 & 41,27 \\
\hline & Simpangan Baku & 5,30 & 4,58 & 4,97 & 5,73 & 5,24 & 6,25 \\
\hline
\end{tabular}

Keterangan: Skor ideal adalah 58,23

Hasil analisis data menunjukkan sekolah maupun secara keseluruhan, bahwa pada masing-masing kategori pembelajaran dengan strategi MHM 
berbasis masalah berpengaruh terhadap kemampuan berpikir kreatif matematis siswa; dengan nilai probabilitas uji (nilai $p$ ) berturut-turut adalah 0,049; 0,001; dan 0,000. Pada sekolah kategori sedang maupun secara keseluruhan, pembelajaran dengan strategi MHM berbasis masalah juga berpengaruh terhadap persepsi siswa terhadap kreativitas. Sebaliknya, pada sekolah kategori atas tidak terdapat pengaruh demikian; dengan nilai $p$ berturut-turut adalah 0,000; 0,001; dan 0,393.

Hasil analisis data menunjukkan bahwa faktor kategori sekolah berpengaruh terhadap persepsi terhadap kreativitas dan sebalimya tidak berpengaruh terhadap kemampuan berpikir kreatif matematis; dengan nilai $p$ berturut-turut adalah 0,000 dan 0,086. Di sisi lain, pada masing-masing kategori sekolah, faktor KAM tidak berpengaruh terhadap persepsi terhadap kre- ativitas; dengan nilai $p$ berturut-turut adalah 0,654 dan 0,394. Pada sekolah kategori atas, faktor KAM berpengaruh terhadap kemampuan berpikir kreatif matematis. Sebaliknya, pada sekolah kategori sedang, tidak terdapat pengaruh demikian; dengan nilai $p$ berturutturut adalah 0,040 dan 0,114.

Hasil analisis data juga menunjukkan bahwa faktor pembelajaran berinteraksi dengan faktor kategori sekolah terhadap persepsi siswa terhadap kreativitas dan sebaliknya faktor pembelajaran tidak berinteraksi dengan faktor kategori sekolah terhadap kemampuan berpikir kreatif matematis; dengan nilai $p$ berturut-turut adalah 0,388 dan 0,017. Interaksi antara faktor pembelajaran dengan faktor kategori sekolah terhadap kemampuan berpikir kreatif matematis dan persepsi terhadap kreativitas berturut-turut disajikan pada Gambar 1 dan Gambar 2 berikut.

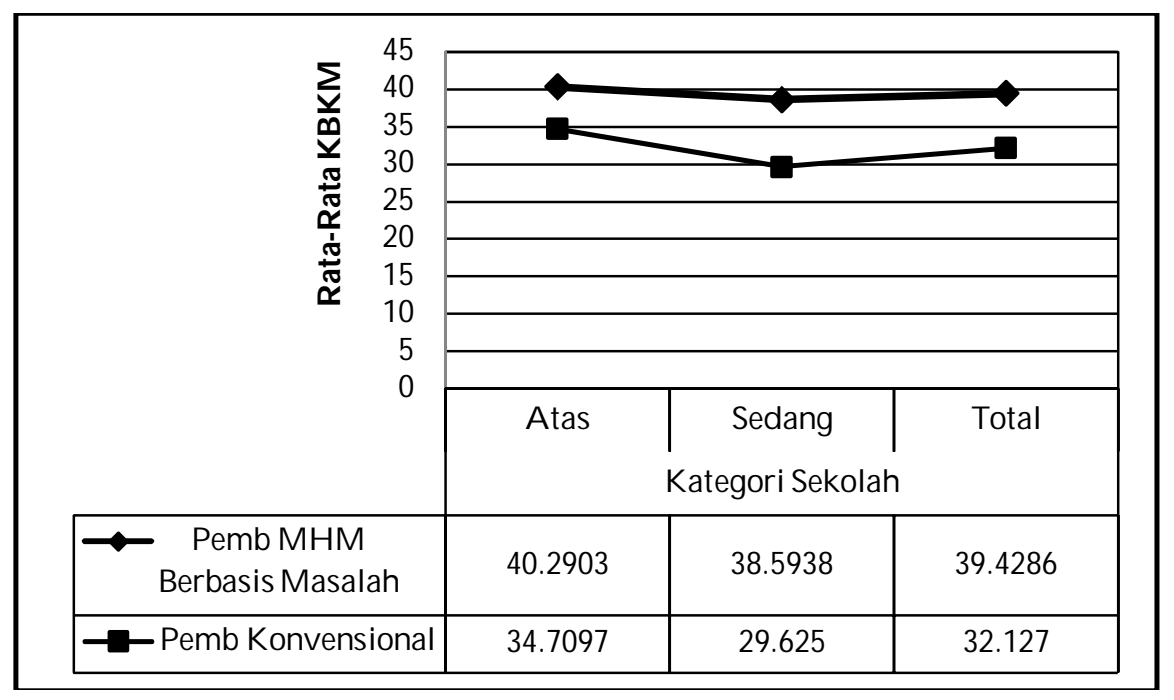

Gambar 1. Grafik Interaksi antara Faktor Pembelajaran dengan Faktor Kategori Sekolah terhadap Kemampuan Berpikir Kreatif Matematis (KBKM 


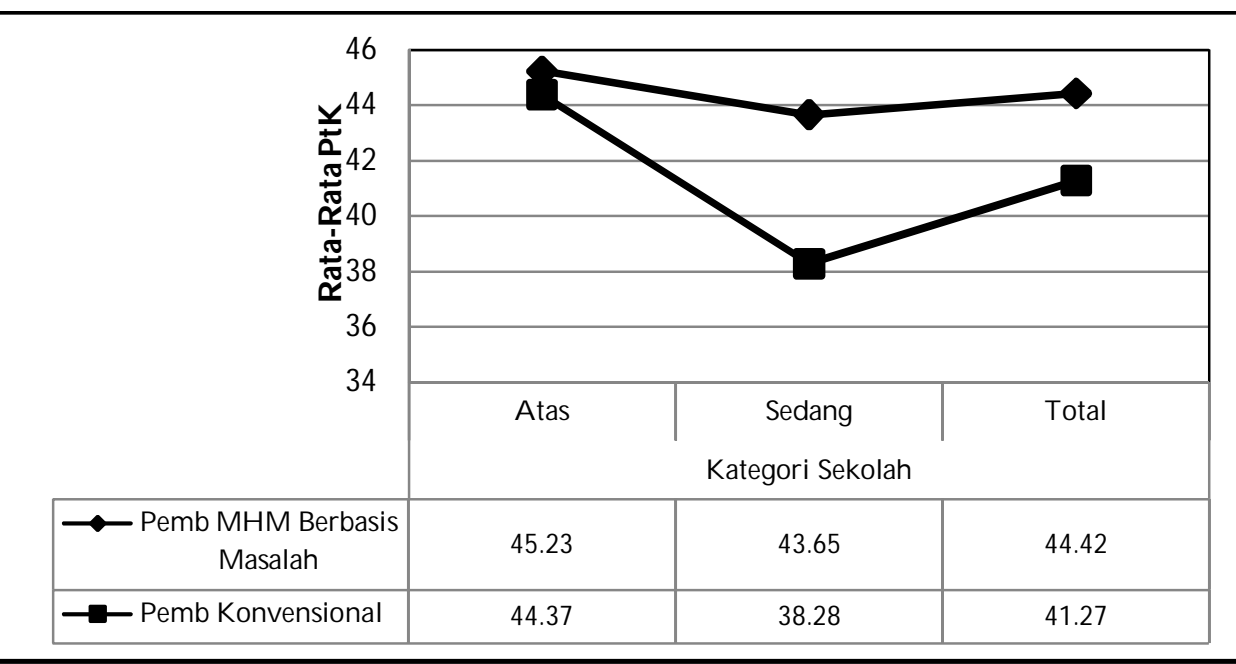

Gambar 2. Grafik Interaksi antara Faktor Pembelajaran dengan Faktor Kategori Sekolah terhadap Persepsi terhadap Kreativitas (PtK)

Hasil analisis data menunjukkan bahwa kemampuan berpikir kreatif matematis siswa berasosiasi dengan persepsi siswa terhadap kreativitas dengan koefisien kontingensi $C=0,508$ dan nilai $p$ adalah 0,005. Berikut disajikan tabel kontingensi antara kemampuan berpikir kreatif matematis dengan persepsi terhadap kreativitas.

Tabel 3. Asosiasi antara Kemampuan Berpikir Kreatif Matematis Siswa dengan Persepsi Siswa terhadap Kreativitas

\begin{tabular}{lcccc}
\hline \multirow{2}{*}{ Persepsi terhadap Kreativitas } & \multicolumn{3}{c}{ Kemampuan Berpikir Kreatif Matematis } \\
\cline { 2 - 5 } & Tinggi & Sedang & Rendah & Total \\
\hline Sangat Tinggi & 2 & 1 & 1 & 4 \\
Tinggi & 0 & 8 & 12 & 20 \\
Sedang & 0 & 15 & 8 & 23 \\
Rendah & 3 & 4 & 8 & 15 \\
Sangat Rendah & 0 & 0 & 1 & 1 \\
\hline Total & 5 & 28 & 30 & 63 \\
\hline
\end{tabular}

\section{PEMBAHASAN}

Hasil penelitian menunjukkan bahwa pembelajaran dengan strategi MHM berbasis masalah berpengaruh terhadap kemampuan berpikir kreatif matematis siswa. Pembelajaran demikian juga berpengaruh terhadap persepsi siswa terhadap kreativitas, terutama pada se- kolah kategori sedang. Temuan ini menunjukkan bahwa strategi MHM berbasis masalah lebih unggul daripada pembelajaran konvensional dalam mengembangkan kemampuan berpikir kreatif matematis siswa maupun persepsi siswa terhadap kreativitas, terutama pada siswa sekolah kategori sedang. 
Temuan ini mengindikasikan bahwa siswa sekolah kategori sedang memperoleh manfaat lebih dari pembelajaran dengan strategi MHM berbasis masalah dalam mengembangkan persepsi siswa terhadap kreativitas.

Keunggulan pembelajaran dengan strategi MHM berbasis masalah dibandingkan pembelajaran secara konvensional dalam mengembangkan kemampuan berpikir kratif matematis dan persepsi siswa terhadap kreativitas dapat dijelaskan sebagai berikut. Kebiasaan mengeksplorasi ide-ide matematis dalam rangkaian pembelajaran dengan strategi MHM berbasis masalah mendorong siswa berpikir fleksibel. Cara berpikir demikian memungkinkan siswa memperoleh berbagai solusi atau strategi penyelesaian masalah. Sangat dimungkinkan salah satu solusi atau strategi tersebut bersifat baru atau unik. Dengan demikian, kebiasaan tersebut dapat mengembangkan aspek-aspek kemampuan berpikir kreatif, yaitu keluwesan dan kebaruan.

Kebiasaan lain yang dibina dalam rangkaian pembelajaran MHM berbasis masalah adalah memformulasi pertanyaan dan mengkonstruksi contoh yang menantang. Kebiasaan demikian merupakan latihan yang baik untuk mengembangkan kemampuan berpikir kreatif matematis siswa dalam aspek kelancaran, keluwesan, dan kebaruan. Penjelasan tersebut sejalan dengan temuan Leung (1997) yang menunjukkan bahwa terdapat hubungan yang signifikan antara kemampuan berpikir kreatif matematis dengan kemampuan mengajukan pertanyaan.
Kebiasaan lain yang dibangun melalui pembelajaran dengan stratgei MHM berbasis masalah adalah mengidentifikasi strategi pemecahan masalah yang dapat diterapkan untuk menyelesaikan masalah dalam skala lebih luas dan bertanya pada diri sendiri apakah terdapat "sesuatu yang lebih" dari aktivitas matematika yang telah dilakukan. Kebiasaan-kebiasaan demikian memungkinkan siswa membangun pengetahuan atau konsep dan strategi mereka sendiri untuk menyelesaikan masalah. Kebiasaan demikian merupakan sejalan dengan filosofi konstruktivisme. Menurut Hein (1996), konstruktivisme mengasumsikan bahwa siswa harus mengkonstruksi pengetahuan mereka sendiri. Kebiasaan demikian memungkinkan siswa mengembangkan potensi kreatifnya. Konstruktivisme dan berpikir kreatif mempunyai ide atau kata kunci sama, yakni mengkonstruksi atau mencipta. Individu dikatakan kreatif apabila ia mampu mencipta atau mengkonstruksi. Sebaliknya dapat dikatakan bahwa pembelajaran dengan filosofi konstruktivisme sebagai proses kreatif.

Masalah kontekstual juga berperan penting sebagai sarana bagi siswa untuk membangun kemampuan berpikir kreatif matematis. Kemampuan tersebut tidak tumbuh di ruang hampa, melainkan memerlukan daya dukung. Menurut Isaken (Alexander, 2007), daya dukung tersebut dapat meliputi konteks, tempat, situasi, iklim, atau faktor sosial. Dalam hal ini, masalah kontekstual berperan sebagai pemicu bagi proses berpikir kreatif siswa untuk melakukan aktivitas-aktivitas kreatif seperti melakukan uji coba, mengajukan dugaan, 
mengeksplorasi berbagai alternatif strategi penyelesaian masalah, dan menyimpulkan untuk menemukan solusi atau strategi kreatif.

Aktivitas belajar siswa secara individual maupun berkolaborasi dengan siswa lain dalam rangkaian pembelajaran dengan strategi MHM berbasis masalah memberi peluang berkembangnya kemampuan aktual dan potensial siswa sesuai dengan teori yang dikemukakan oleh Vigotsky (1978). Perkembangan aktual diperoleh ketika siswa melakukan aktivitas matematis seperti menyelesaikan masalah matematis secara individual dan perkembangan potensial dicapai ketika siswa berinteraksi dengan orang lain dengan kemampuan lebih tinggi. Dalam konteks pembelajaran, orang lain tersebut adalah guru atau teman diskusi kelompok yang memiliki kemampuan lebih. Perkembangan potensial ini dapat dipicu dengan masalah yang menantang.

Kebiasaan matematis yang dilakukan secara bersinambung juga dapat menumbuhkan persepsi yang tepat terhadap kreativitas. Ketika siswa menemukan beragam solusi atau strategi penyelesaian masalah, mereka akan meyakini bahwa masalah matematis dapat memiliki lebih dari satu jawaban atau strategi. Selain itu, ketika siswa menyadari bahwa ia dapat menyelesaikan suatu masalah dengan strategi mereka sendiri, siswa juga akan memandang positif diri mereka sendiri.

Dari Tabel 1 diketahui bahwa kecuali pada sekolah kategori sedang, semakin tinggi kemampuan awal matematis (KAM) siswa, semakin tinggi pula kemampuan berpikir kreatif matematis- nya. Temuan ini menunjukkan bahwa faktor KAM berpengaruh terhadap terhadap kemampuan berpikir kreatif matematis siswa. Dari Tabel 1 diketahui pula bahwa siswa dengan kategori KAM tinggi pada sekolah kategori atas lebih banyak daripada siswa dengan kategori KAM tinggi pada sekolah kategori sedang. Selain itu, siswa dengan kategori KAM rendah pada sekolah kategori sedang lebih banyak daripada siswa dengan KAM rendah pada sekolah kategori atas. Temuan ini menggambarkan bahwa katagori sekolah sejalan dengan kategori KAM.

Hasil penelitian menunjukkan bahwa faktor KAM tidak berpengaruh terhadap persepsi terhadap kreativitas. Hal ini menunjukkan bahwa tidak terdapat perbedaan persepsi siswa terhadap kreativitas antarkategori KAM. Dari Tabel 2 diketahui bahwa siswa dengan KAM rendah memiliki persepsi yang lebih baik terhadap kreativitas daripada siswa dengan kategori KAM lebih tinggi. Temuan ini mengindikasikan bahwa siswa dengan kategori KAM rendah memperoleh manfaat lebih dari strategi MHM berbasis masalah dalam mengembangkan persepsi terhadap kreativitas. Temuan ini sejalan dengan temuan lain yang menunjukkan bahwa siswa sekolah kategori sedang memperoleh manfaat lebih dari strategi MHM berbasis masalah dalam pencapaian kemampuan berpikir kreatif matematis. Di sisi lain, kategori KAM sejalan dengan kategori sekolah.

Hasil penelitian menunjukkan bahwa faktor kategori sekolah berpengaruh terhadap persepsi terhadap kreativitas dan sebaliknya tidak berpengaruh 
terhadap kemampuan berpikir kreatif matematis siswa. Hasil analisis lebih lanjut dengan uji-t menunjukkan bahwa siswa sekolah kategori atas yang mengikuti pembelajaran secara konvensional memiliki kemampuan berpikir kreatif matematis yang lebih baik daripada siswa sekolah kategori sedang yang mengikuti pembelajaran demikian. Di sisi lain, tidak terdapat perbedaan kemampuan berpikir kreatif matematis siswa yang mengikuti pembelajaran dengan strategi MHM berbasis masalah antarkategori sekolah. Temuan demikian mengindikasikan bahwa siswa sekolah kategori sedang memperoleh manfaat lebih dari pembelajaran dengan strategi MHM berbasis masalah dalam pencapaian kemampuan berpikir kreatif matematis.

Sebagaimana diuraikan di atas, siswa dengan kategori KAM rendah dan siswa sekolah kategori sedang memperoleh manfaat lebih dari strategi MHM berbasis masalah dalam pencapaian kemampuan berpikir kreatif matematis dan persepsi terhadap kreativitas. Manfaat lebih ini diduga kuat disebabkan oleh karateristik bahan ajar yang digunakan, yaitu LKS. LKS ini memuat masalah-masalah kontekstual disertai pertanyaan-pertanyaan acuan yang bersifat terstruktur guna membantu proses belajar siswa. Karakteristik bahan ajar demikian sangat membantu siswa dengan KAM rendah atau siswa sekolah kategori sedang.

Manfaat lebih yang diperoleh siswa dengan KAM rendah dalam pencapaian kemampuan berpikir kreatif matematis juga disebabkan oleh faktor keterlibatan siswa dalam aktivitas diskusi. Melalui aktivitas diskusi, siswa saling berbagi pengetahuan. Siswa dengan kemampuan matematis tinggi dapat lebih memperkokoh pemahamannya, sedangkan siswa dengan kemampuan matematis rendah dapat memperoleh pemahaman yang lebih baik ketika memperoleh penjelasan dari teman mereka yang mungkin lebih mudah dipahami. Hal demikian sejalan dengan pendapat Vigotsky (1978) bahwa melalui interaksinya dengan siswa lain, siswa dapat mengembangkan kemampuan potensialnya.

Hasil penelitian juga menunjukkan bahwa bahwa faktor pembelajaran berinteraksi dengan faktor kategori sekolah terhadap persepsi terhadap kreativitas. Sebaliknya, faktor pembelajaran tidak berinteraksi dengan faktor kategori sekolah terhadap kemampuan berpikir kreatif matematis. Temuan ini menunjukkan bahwa pengaruh pembelajaran dengan strategi MHM berbasis masalah terhadap persepsi terhadap kreativitas bergantung pada kategori sekolah. Sebaliknya, pengaruh pembelajaran demikian terhadap kemampuan berpikir kreatif matematis tidak bergantung pada kategori sekolah. Dapat dikatakan bahwa pengaruh pembelajaran dengan strategi MHM berbasis masalah terhadap kemampuan berpikir kreatif matematis pada masing-masing kategori sekolah adalah serupa. Dengan kata lain, pembelajaran dengan strategi MHM berbasis masalah relatif sesuai untuk mengembangkan kemampuan berpikir kreatif matematis siswa pada sekolah kategori atas maupun sedang. Di sisi lain, pembelajaran demikian relatif lebih sesuai untuk mengembangkan 
persepsi terhadap kreativitas siswa sekolah kategori sedang.

Hasil penelitian menunjukkan bahwa kemampuan berpikir kreatif matematis berasosiasi dengan persepsi terhadap kreativitas. Temuan ini menunjukkan bahwa siswa yang memiliki persepsi yang positif terhadap kreativitas cenderung memiliki kemampuan berpikir kreatif matematis yang baik. Sebaliknya, siswa yang memiliki persepsi yang kurang tepat terhadap kreativitas cenderung memiliki kemampuan berpikir kreatif matematis yang rendah. Temuan ini sejalan dengan hasil penelitian Mann (2005) yang menunjukkan bahwa persepsi terhadap kreativitas merupakan salah satu penduga yang baik bagi kreativitas.

\section{PENUTUP}

Berdasarkan hasil analisis data disimpulkan bahwa pembelajaran dengan strategi MHM berbasis masalah berpengaruh terhadap pencapaian kemampuan berpikir kreatif matematis. Pembelajaran demikian juga berpengaruh terhadap pencapaian persepsi siswa berkaitan dengan kreativitas, terutama pada sekolah kategori sedang. Selain itu, disimpulkan bahwa tidak terdapat interaksi antara faktor pembelajaran dengan faktor kategori sekolah terhadap kemampuan berpikir kreatif matematis. Sebaliknya, terdapat interaksi antara faktor pembelajaran dengan faktor kategori sekolah terhadap persepsi terhadap kreativitas. Disimpulkan juga bahwa kemampuan berpikir kreatif matematis berasosiasi dengan persepsi terhadap kreativitas.
Implikasi penting penelitian ini adalah bahwa kebiasaan-kebiasaan berpikir matematis yang dilakukan secara bersinambung melalui aktivitas diskusi untuk mengeksplorasi masalah kontekstual mendukung pencapaian kemampuan berpikir kreatif matematis siswa dan persepsisiswa terhadap kreativitas. Berdasarkan hasil penelitian ini direkomendasikan bahwa strategi pembelajaran dengan strategi MHM berbasis masalah dapat digunakan sebagai alternatif untuk mengembangkankan kemampuan berpikir kreatif matematis dan persepsi terhadap kreativitas. Selain itu, direkomendasikan pula bahwa pengembangan kemampuan berpikir kreatif matematis siswa perlu dilakukan secara simultan dengan pengembangan persepsi siswa terhadap kreativitas.

Peneliti mengucapkan terima kasih kepada kepala sekolah atas azin dan fasilitas yang diberikan kepada penulis untuk melakukan penelitian ini. Peneliti juga mengucapkan terima kasih kepada guru-guru mitra maupun seluruh siswa yang terlibat dalam penelitian ini atas kesediaan bekerja sama dan berbagi pengalaman dengan peneliti.

\section{UCAPAN TERIMA KASIH}

Pada kesempatan ini, terima kasih kami ucapkan kepada Redaktur yang telah memberi masukan yang berharga sehingga tulisan ini dapat disajikan di Jurnal Cakrawala Pendidikan. Terima kasih juga kami ucapkan kepada seluruh pengurus Jurnal Cakrawala Pendidikan yang telah memberi ruang diskusi. 


\section{DAFTAR PUSTAKA}

Alexander, K. L. 2007. Effects Instruction in Creative Problem Solving on Cognition, Creativity, and Satisfaction among Ninth Grade Students in an Introduction to World Agricultural Science and Technology Course. http://etd.lib.ttu.edu/theses/availa ble/etd-01292007-44648/unrestricted/ Alexander_Kim__Dissertation.pdf, Diunduh 9 Mei 2008.

Berg, R. A. 1999. Social Constructions of Creativity in a Middle School Math Classroom. http:/wwww.jrrb.com/examples/SocialConst_Creativity. pdf. Diunduh 9 Mei 2008.

Briggs, M \& Davis, S. 2008. Creative Teaching Mathematics in the Early Years \& Primary Classrooms. New York USA: Madison Ave.

Career Center Maine Departmeny of Labor. 2001. Today's Work Competence in Maine. http:/Wwww.maine.gov /abor/1mis/pdf/Essenti alWorkCompe-tencies.pdf. Diunduh 9 Mei 2008.

Center for Instructional Development \& Research. 2004. Problem-Based Learning. http://depts.washington.edu/cidrweb/Bulletin/PBL.ht ml. Diunduh 16 Maret 2009.

Depdiknas. 2004. Kurikulum 2004. Standar Kompetensi Mata Pelajaran Matematika Sekolah Menengah Pertama dan Madrasah Tsanawiyah. Jakarta: Depdiknas.
Fogarty, R. 1997. Problem-Based Learning and Other Curriculum Models for the Multiple Intelligences Classroom. Australia: Hawker Brownlow.

Grieshober, W. E. 2004. Continuing a Dictionary of Creativity Terms $\mathcal{E}$ Definition. http://www. Buffalostate.edu/orgs/cbir/ReadingRoom /theses/Grieswep.pdf. Diunduh 7 Juni 2008.

Hein, G. E. 1996. Constructivism Learning Theory. http://www. Exploratorium.edu/fí/resources/constructivi stlearning.html. Diunduh 15 Mei 2009.

Leung, S. S. 1997. On the Role of Creative Thinking in Problem Posing. http://www.fiz.karlsruhe.de/fiz/public ations/zdmZDM Volum 29 Number 3. Electronic Edition ISSN 1615-679X. Diunduh 6 Agustus 2002.

Livne, N. L. 2008. Enhanching Mathematical Creativity through Multiple Solution to Open-Ended Problems Online, dari http://www.iste.org/ Content. NavigationMenu/Rese$\operatorname{arch}$ NECC_Research_Paper_Arc hives NECC2008/Livne.pdf. Diunduh 7 Mei 2009.

Mann, E. L. 2005. Mathematical Creativity and School Mathematics: Indicators of Mathematical Creativity in Middle School Students. Disertasi University of Connecticut. http:// www.gifted.uconn.edu/Siegle/Di 
ssertations/Eric\%20Mann.pdf.

Diunduh 15 November 2007.

Martin. 2009. Convergent and Divergent Thinking. http://www. Eruptingmind.com/convergent-divergentcreative-thinking/. Diunduh [20 Maret 2009.

Matlin, M.W. 2003. Cognition. Fifth Edition. USA: John Wiley \& Sons, Inc.

McGregor, D. 2007. Developing Thinking Developing Learning. Poland: Open University Press.

Millman, R. S. \& Jacobbe, T. 2008. "Fostering Creativity in Preservice Teachers through Mathematical Habits of Mind. Proceeding of the Discussing Group 9". The 11 th International Congress on Mathematical Education. Monterrey, Mexico, July 2008. http://dg.icme11.org/document/get/272. Diunduh 19 Desember 2008.

Permana, Y. 2004. "Pengembangan Kemampuan Penalaran dan Koneksi Matematis Siswa SMA melalui Pembelajaran Berbasis Masalah". Tesis pada Sekolah Pascasarjana UPI. Tidak diterbitkan.
Ratnaningsih, N. \& Herman, T. 2006. "Developing the Mathematical Reasoning of High School Students through Problem Based Learning". Transaction of Mathematical Education for College and University Vol.9 No.2 Japan Society of Mathematics Education, Division for College and University.

Roh, K. H. 2003. Problem-Based Learning in Mathematics. Artikel pada Educational Resources Information Center (ERIC). http:/wwww. Ericdigests.org/2004-3/math.html. Diunduh 19 Maret 2009.

Ruseffendi, H. E. T. 2005. Dasar-dasar Penelitian Pendidikan \& Bidang Non-Eksakta Lainnya. Bandung: Tarsito.

Sternberg, R.. 2006. Creativity as a Habit. http:/www. Worldscibooks.com/etextbook/6211/6211_chap01.pdf. Diunduh 11 Januari 2009.

Vygotsky, L. 1978. Mind in Society: The Development of Higher Mental Processes. Cambridge, MA, Harvard University Press. 